\title{
MODEL SISTEM PENDAFTARAN SEKOLAH UNTUK MONITORING PEMETAAN WILAYAH SEBAGAI PENUNJANG KEPUTUSAN PENERIMAAN SISWA BARU
}

\author{
Rudy Yandri ${ }^{1}$ \\ Fernando Siboro ${ }^{2}$ \\ Dina Yantika Wusni Simanjuntak ${ }^{3}$ \\ Dosen STMIK Raharja ${ }^{1,2}$ \\ STMIK Raharja Jurusan Teknik Informatika ${ }^{3}$ \\ Jl. Jendral Sudirman No. 40, Kota Tangerang, Banten ${ }^{1,2,3}$ \\ Email:rudy.yandri@raharja.info, ${ }^{1}$, fernando.siboro@raharja.info ${ }^{2}$,dina.yantika@raharja.info ${ }^{3}$
}

\begin{abstract}
ABSTRAK
Pendaftaran siswa baru yang dilakukan dibeberapa sekolah saat ini masih menggunakan sistem manual, sehingga menyebabkan pihak sekolah merasa kesulitan untuk mengatur proses penerimaan siswa baru, seperti pengolahan data-data dan pembuatan laporan-laporan.Selain itu kecepatan, ketepatan, ketelitian hasil laporan juga menjadi masalah dalam pengambilan keputusan sekolah untuk menerima calon siswa baru. Dibeberapa sekolah penerimaan siswa baru setiap tahunnya mencapai sekitar 300 orang. Salah satu cara untuk menjamin keakuratan informasi yang dibutuhkan dan kenyamanan para calon siswa baru dalam proses pendaftaran dan pelaksanaan ujian. Untuk dapat memberikan solusi dalam mengatasi permasalahan ini, penulis mencoba membuat sebuah bentuk design sistem dalam bentuk use case diagram, squence diagram, activity diagram dan class diagram, yang kemudian penulis mencoba mengimplementasikan dalam bentuk prototype sistem menggunakan aplikasi web. Oleh sebab itu, peranan internet sangat diperlukan untuk lancarnya proses penerimaan siswa baru. Tujuan dari pembuatan sistem ini adalah untuk membantu memonitoring data penerimaan siswa baru yang lebih efektif dan efisien dalam penunjang keputusan. Selain itu juga, sekolah diharapkan mampu menganalisis capaian penerimaan siswa baru berdasarkan kategori tertentu, seperti berdasarkan wilaah, jenis kelami, bakat, ekonomi orang tua, dan lain sebagainya. Dimana informasi yang berhasil diciptakan ini diharapkan mampu menjadi data dalam menunjang keputusan yang akan diambil oleh kepala sekolah.
\end{abstract}

Kata kunci : Siswa baru, pemetaan wilayah, penunjang keputusan

\begin{abstract}
ABASTRACT
Registration of new students conducted in several schools is currently still using a manual system, which causes the school to find it difficult to regulate the process of accepting new students, such as processing data and making reports. Besides speed, accuracy, accuracy of the results of the report also become a problem in making school decisions to accept new prospective students. In some schools new student admissions reach around 300 people each year. One way to ensure the accuracy of the information needed and the convenience of prospective students is in the process of registering and conducting examinations. To be able to provide a solution to overcome this problem, the author tries to make a form of system design in the form of use case diagrams, squence diagrams, activity diagrams and class diagrams, which the author tries to implement in the form of a system prototype using a web application. Therefore, the role of the internet is very necessary to smooth the process of accepting new students. The purpose of making this system is to help monitor new student admission data that is more effective and efficient in supporting decisions. Besides that, the school is expected to be able to analyze the achievement of new student admissions based on certain categories, such as based on area, gender, talent, economic parents,
\end{abstract}


and so forth. Where information that was successfully created is expected to be able to become data in supporting the decisions that will be taken by the principal..

Keywords: New students, regional mapping, decision support

\section{PENDAHULUAN}

Perkembangan ilmu pengetahuan dan teknologi yang sangat pesat di semua bidang dan permintaan pelayanan yang nyaman khususnya dalam mendapatkan informasi menyebabkan timbulnya kebutuhan sistem komputerisasi untuk mendapatkan informasi sehingga dapat mengikuti perkembangan jaman. Hal ini dikarenakan komputer dan internet mampu memegang peranan penting sebagai alat bantu dalam pengolahan data dan pencarian informasi serta dapat memecahkan masalah-masalah yang timbul mulai dari masalah yang sederhana sampai masalah yang rumit. Penggunaan komputer yang dilengkapi dengan program aplikasi yang dapat memberikan hasil yang berkualitas, dan internet yang bisa digunakan untuk mendapatkan informasi tanpa harus pergi ke tempat yang dimaksud.

Berdasarkan latar belakang yang telah di uraikan diatas, maka masalah yang akan dibahas pada penelitian ini adalah bagaimana sistem pendaftaran siswa yang sedang berjalan saat ini disekolah, apakah sistem pendaftaran siswa yang sedang berjalan saat ini di sekolah sudah efektif dan efisien, apakah sistem pendaftaran siswa yang sedang berjalan saat ini sudah mampu menciptakan laporan dengan cepat dan akurat.

\section{METODE PENELITIAN}

Metode penelitian merupakan suatu tata cara atau kegiatan pelaksanaan penelitian rangka untuk mengumpulkan informasi atau data serta melakukan investigasi terhadap data yang telah didapatkan tersebut. yang didasari oleh asumsi-asumsi dasar, pandanganpandangan filosofis dan ideologis, pertanyaan dan isu-isu yang dihadapi. Suatu penelitian mempunyai rancangan penelitian tertentu. Rancangan ini menggambarkan prosedur atau langkah-langkah yang harus ditempuh, waktu penelitian, sumber data dan kondisi arti untuk apa data dikumpulkan dan dengan cara bagaimana data tersebut dihimpun dan diolah untuk dianalisa dalam pembuatan laporan.

\section{Metode Observasi (Observasi Research)}

Pada tahapan ini penulis melakukan pengamatan langsung dari objek penelitian untuk mendapatkan data dan informasi yang akurat dan lengkap dari berbagai pihak yang terkait dan berhubungan dengan tema penelitian yang berhasil penulis rumuskan di bagian finance.

\section{a. Metode Wawancara (Interview Research)}

Penulis melakukan wawancara dengan kepala sekolah, bagian marketing dan beberapa guru serta siswa yang berkaitan dengan penelitian penulis.

b. Metode Studi Pustaka (Studi Literature)

Selain melakukan Observasi penulis juga melakukan data dengan cara studi pustaka dalam metode ini penulis berusaha untuk melengkapi data-data yang diperoleh dengan membaca dan mempelajari dari buku-buku dan data-data yang relevan dalam pemilihan judul yang penulis ajukan. Buku dan data tersebut digunakan penulis untuk membantu penganalisaan dan perancangan yang dilakukan. 


\section{Metode Analisis Data}

Pada penelitian ini, metode analisa dilakukan dengan langkah-langkah melakukan pengamatan dan analisa terhadap sistem yang berjalan saat ini, serta menentukan UML (Unified Modeling Language) yang meliputi use case diagram, activity diagram, sequence diagram.

\section{LITERATUR REVIEW}

Literature review adalah suatu survey literature tentang penemuan-penemuan yang telah dilakukan oleh penelitian sebelumnya yang berhubungan dengan topik penelitian.

1. Penelitian yang telah dilakukan oleh Ryan Anggara (2015)

Penelitian ini berjudul "APLIKASI SISTEM PENERIMAAN SISWA BARU BERBASIS WEB UNTUK PEMETAAN DALAM MENUNJANG PENGAMBILAN KEPUTUSAN PADA SMK LAB BUSINESS SCHOOL TANGERANG". Sistem penerimaan siswa baru yang berjalan pada SMK Lab Business School Tangerang saat ini masih sudah menggunakan komputer namun baru sebatas office dan karenanya memerlukan waktu yang cukup lama dalam proses penyimpanan data.

2. Penelitian yang telah dilakukan oleh Siti Khuzaemah(2016)

Penelitian ini berjudul "PERANCANGAN SISTEM PENDUKUNG KEPUTUSAN PENILAIAN KINERJA ORGANISASI MENGGUNAKAN METODE SIMPLEADDITIVE WEIGHTING (SAW)PADA KEMENKO BIDANG PEREKONOMIAN JAKARTA PUSAT"pada tahun 2016. Dalam sistem pendukung keputusan penilaian kinerja organisasi metode yang digunakan dalam melakukan perhitungan penilaian kinerja organisasi menggunakan metode Simple Additive Weighting (SAW) yang diharapkan dapat mempermudah dalam melakukan perhitungan penilaian kinerja organisasi.

3. Penelitian yang telah dilakukan oleh Azwar Zari (2016)

Penelitian ini tentang "IMPLEMENTASI APLIKASI PENDAFTARAN ONLINE

SEBAGAI SERVICE PADA CLOUD COMPUTING DI

KOPERTAISWILAYAH VII". Oleh karena itu aplikasi Pendaftaran Mahasiswa Baru ini haruslah dapatdiakses melalui internet atau bersifatonline. Keuntungan yang diperoleh denganadanya sistemonlineini adalah Perguruan Tinggi dapat membuka peluang mendaftarbagi calon mahasiswa yang berasal dari tempat yang jauh. Selain itu calon mahasiswadapat melakukan proses pendaftaran secara efektif dan efisien. Aplikasi ini akansangat membantu pihak universitas dan calonmahasiswa untuk mendapatkan informasi kapanpun dan dimanapun.

4. Penelitian yang dilakukan oleh ASLAM RIZAL NURDIN (2017)

Penelitian ini tentang"SISTEM INFORMASI SEKOLAH DAN PENERIMAAN SISWA BARU PADA SMK MUHAMMADIYAH 3 DOLOPO MENGGUNKAN PHP DAN MYSQL". Sistem pendaftaran siswa baru di SMK Muhammadiyah 3 Dolopo secara keseluruhan masih menggunakan proses manual, walaupun sebagian sudah menggunakankomputer,akibatnya jangkauannya informasinya lebih sempit, dimana informasi mengenai sekolah ini hanya diperoleh melalui brosur-brosur, sepanduk dan baligho. Selain itu, akibat dari proses pendaftaran manual ini adalah proses pengambilan serta pengembalian formulir yang bagi sebagian calon siswa cukup menyulitkan terutama bagi calon siswa yang tinggal jauh dari Sekolah ini.Dengan dibuatnya sistem informasi sekolah dan penerimaan siswa baru secara 
online Di SMKMuhammadiyah 3 Dolopo diharapkan dapat menjadi media promosi SMK Muhammadiyah 3 Dolopo serta akan membuat pelaksanaan penerimaan siswa barumenjadi lebih transparan, akuntabel, dan akomodatif. Sekolah dapat mengurangi anggaran yang digunakan untuk promosi dan bahkan menghilangkan kecurangankecurangan yang terjadi pada pelaksanaan penerimaan siswa baru secara manual. Dengan demikian, tidak akan ada lagi pihak-pihak yang merasa tidak puas ataupun dirugikan.

\section{PEMBAHASAN}

Untuk dapat menggambarkan prosedur secara keseluruhan diperlukan bebrapa tahapan analisa sebagai bentuk pengumpulan informasi guna mendapatkan model yang sesuai dengan kebutuhan dan mampu memberikan solusi dengan cepat secara efektif dan efisien, mulai dari tahapan pengumpulan informasi dan kebutuhan, analisa dokumen, merancangan hubungan antar dokumen sampai dengan merancanga model diagram database dan model rancangan sistem. Beberapa tahapan yang dimaksud sampai dengan model ranangan yang diciptakan dapat dilihat pada gambar 1,2,3,4,4.

\section{Use Case Diagram}

Diagram use case digunakan untuk memperlihatkan hubungan antara actor case yang ada dalam sistem. Sehingga calon pengguna sistem mendapatkan pemahaman tentang sistem yang akan di rancang. 


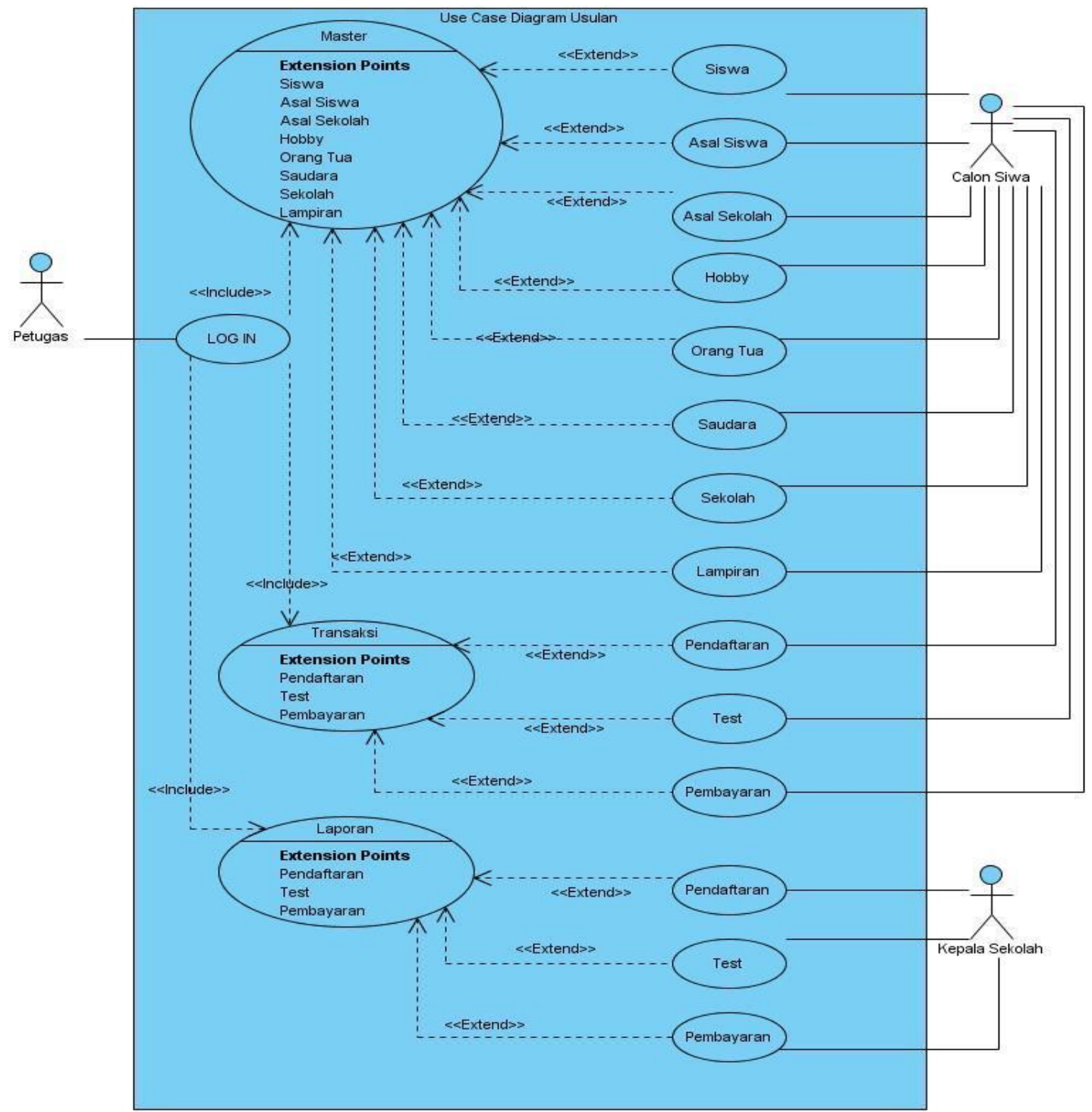

Gambar 1.Use Case Diagram

Pada gambar diatas (gambar 1) merupakan rancangan sistem dalam bentuk use case diagram. Menerangkan kegiatan admin PSB selaku pengguna sistem dalam penginputan pendaftaran. yang dapat langsung memberikan laporan ke Kepala Sekolah. Terdapat 3 (tiga) use case utama yaitu master yang berfungsi sebagai menu untuk kebutuhan pengelolaan data master, kemudian terdapat juga menu pendaftaran dimana calon siswa dapat melakukan langsung proses pendaftaran secara online, selain itu juga terdapat menu untuk pelaksanaan test secara online, juga terdapat menu laporan untuk kebutuhan kepala sekolah ketika membutuhkan berbagai informasi dengan cepat dan akurat. 


\section{Activity Diagram}

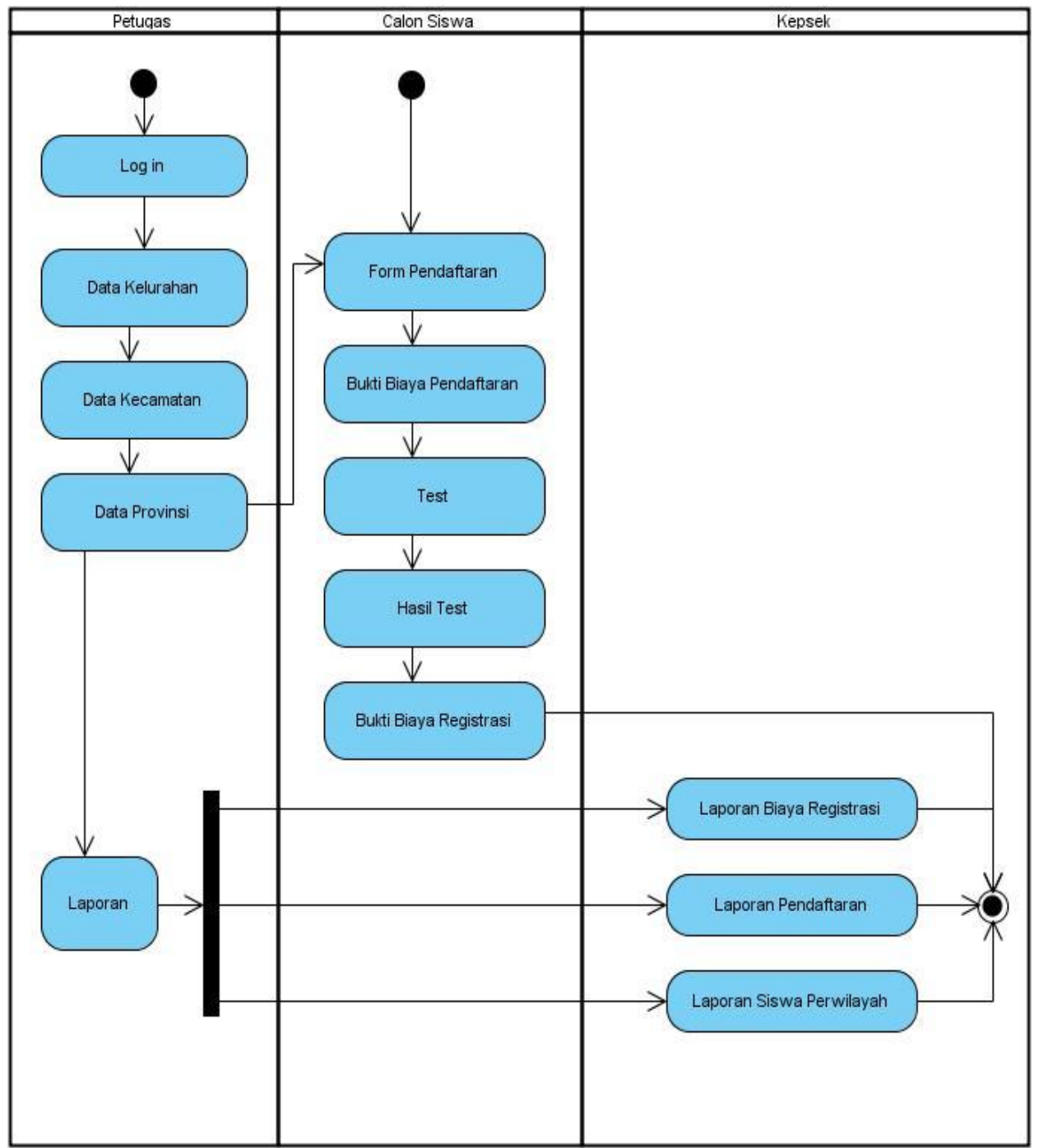

Gambar 2. Activity Diagram

Activity diagram $m$ (gambar 2) menggambarkan berbagai alur aktifitas dalam sistem yang di rancang, pada gambar diatas menjabarkan tentang alur proses mulainya input pendaftaran sampai berakhir pada pencetakan pendaftaran yang nantinya akan diberikan kepada orang tua siswa. Penggambaran activity diagram ini melibatkan seluruh actor yang ada di usecase, dimana setiap actor akan menjadi 1 (satu) kolom, untuk dapat menjelaskan alur proses secara visual.

\section{Class Diagram}




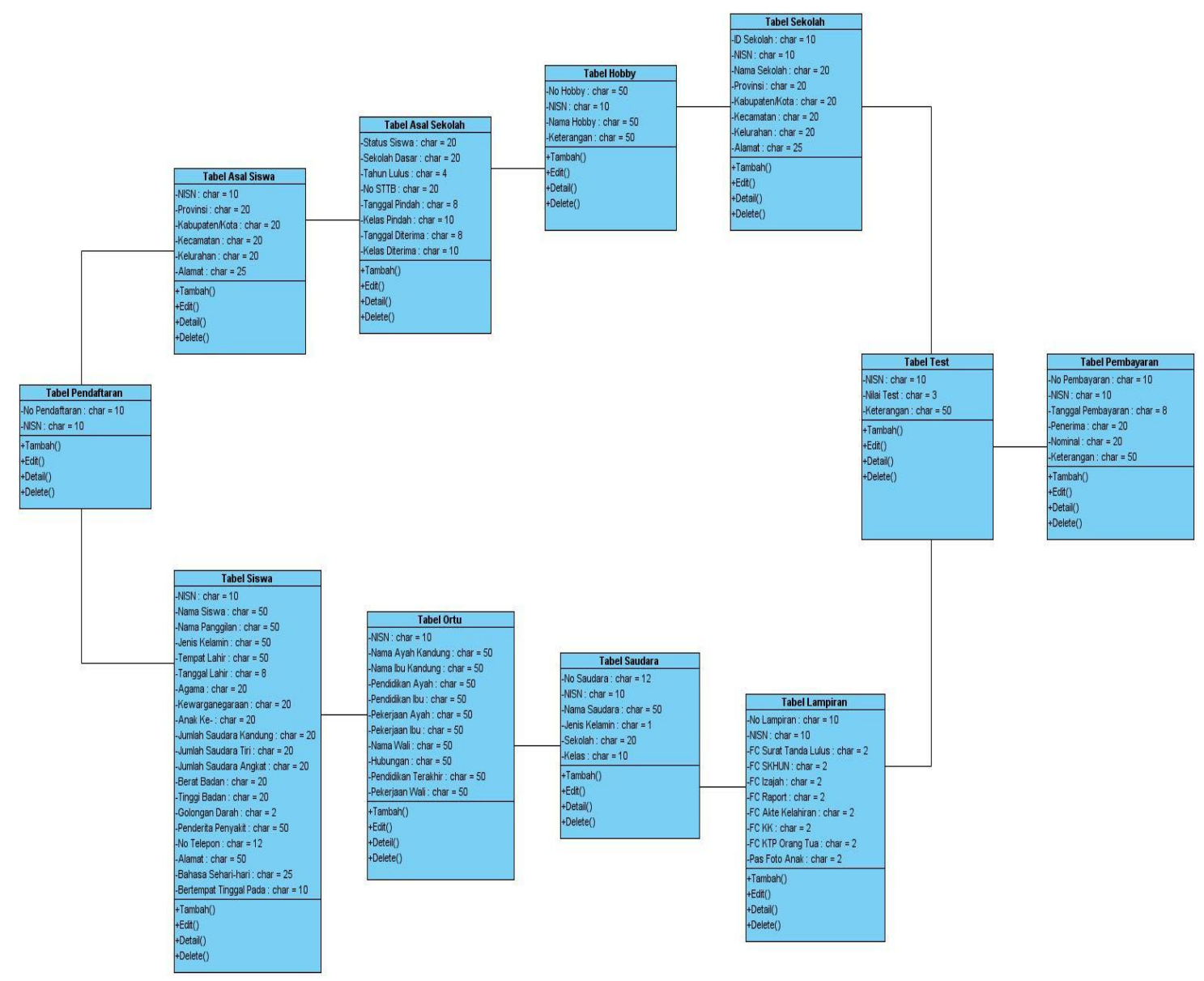

Gambar 3. Class Diagram

Pada gambar diatas (gambar 3) merupakan ranangan basisdata dalam bentuk class diagram. Dalam class diagram ini terdapat beberapa tabel sesuai kebutuhan berdasarkan hasil analisa kebutuhan, dan seluruh tabel akan disatukan dalam satu database. Terdapat 11 (sebelas) tabel untuk dapat menjalankan sistem ini, dimana setiap tabel akan menyimpan data calon siswa sesuai objeknya. 


\section{IMPLEMENTASI}

\section{Tampilan Menu Login}

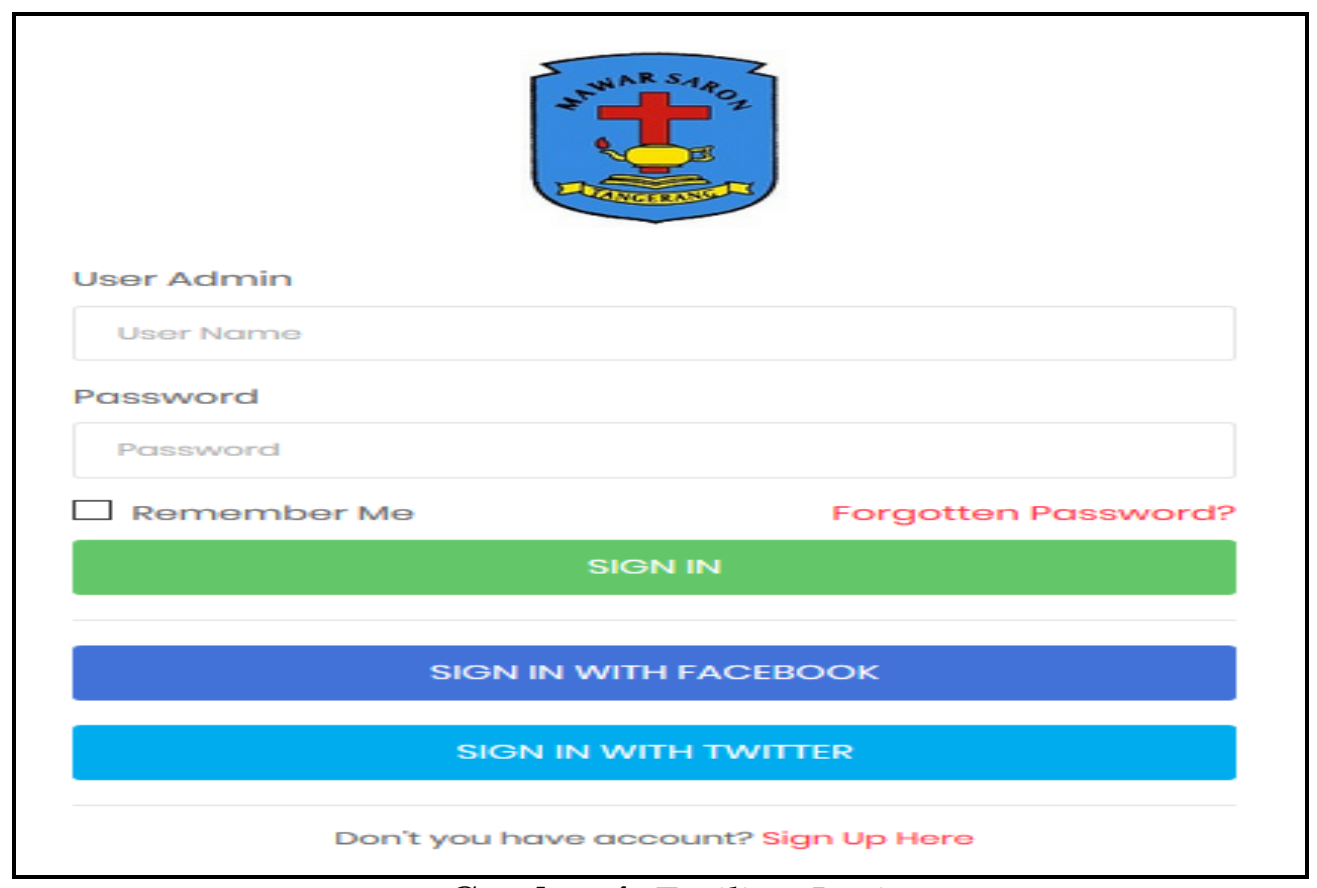

Gambar 4. Fasilitas Login

Pada gambar diatas menampilkan halaman utama login. Kegunaan menu login tersebut agar tidak sembarangan orang dapat mengakses atau menggunakan sistem pendaftaran sekolah untuk monitoring pemataan wilayah sebagai penujang keputusan penerimaan siswa baru .Yang dapat mengkases program ini adalah admin PSB dan Pimpinan Sekolah yang telah memiliki username dan password.

\section{Tampilan Menu Dashboard}

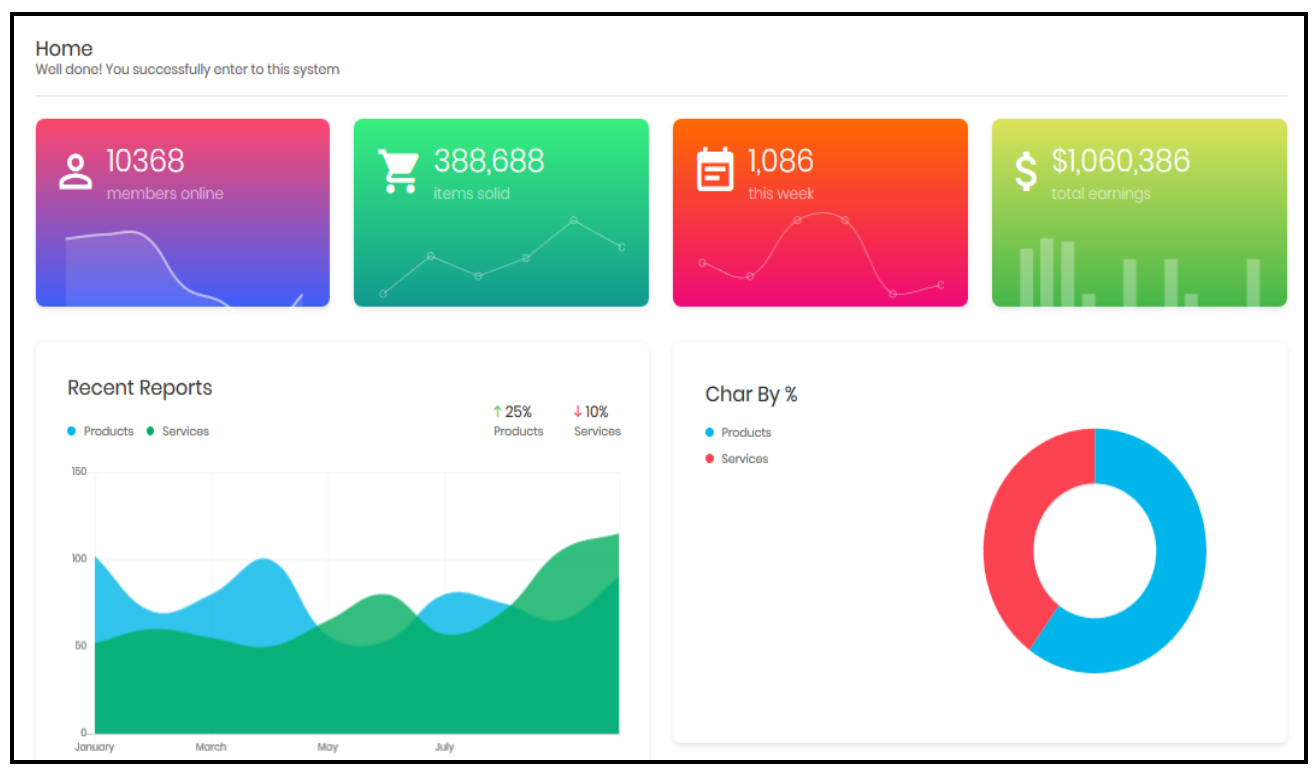

Gambar 5. Dashboard 


\section{Tampilan Layar Pengelola Data}

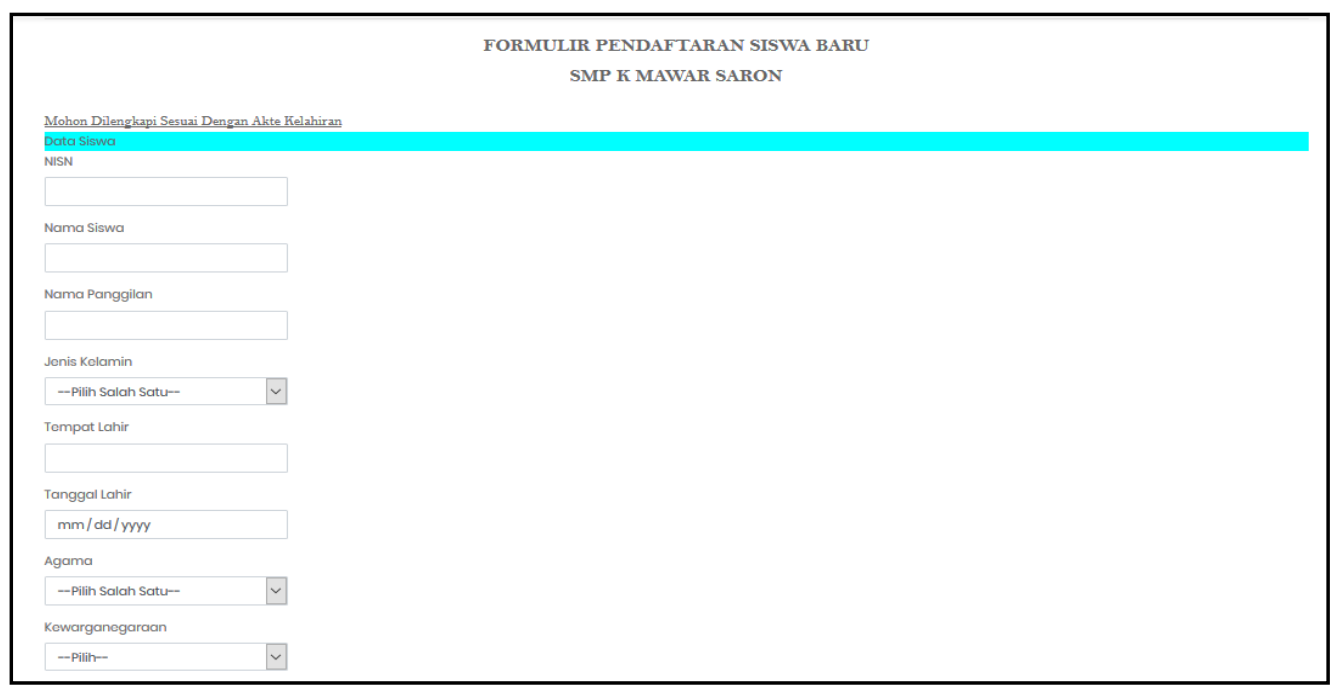

Gambar 6. Layar Pengelolaan Data

Pada gambar (gambar 6) diatas dimana user yang telah login akan otomatis masuk kedalam dashboard, pada dashboard terdapat beberapa pilihan menu yaitu, Data Master, Data Transaksi data Data Laporan. Penggunaan fasilitas dasboard ini dimaksudkan untuk memonitoring pendaftaran siswa yang dapat diolah berdasarkan kebutuhan, tertutama dalam memoitoring pemetaan wilayah, agar sekolah mendapatkan wawasan dari daerah mana aja asal siswa yang mendaftar.

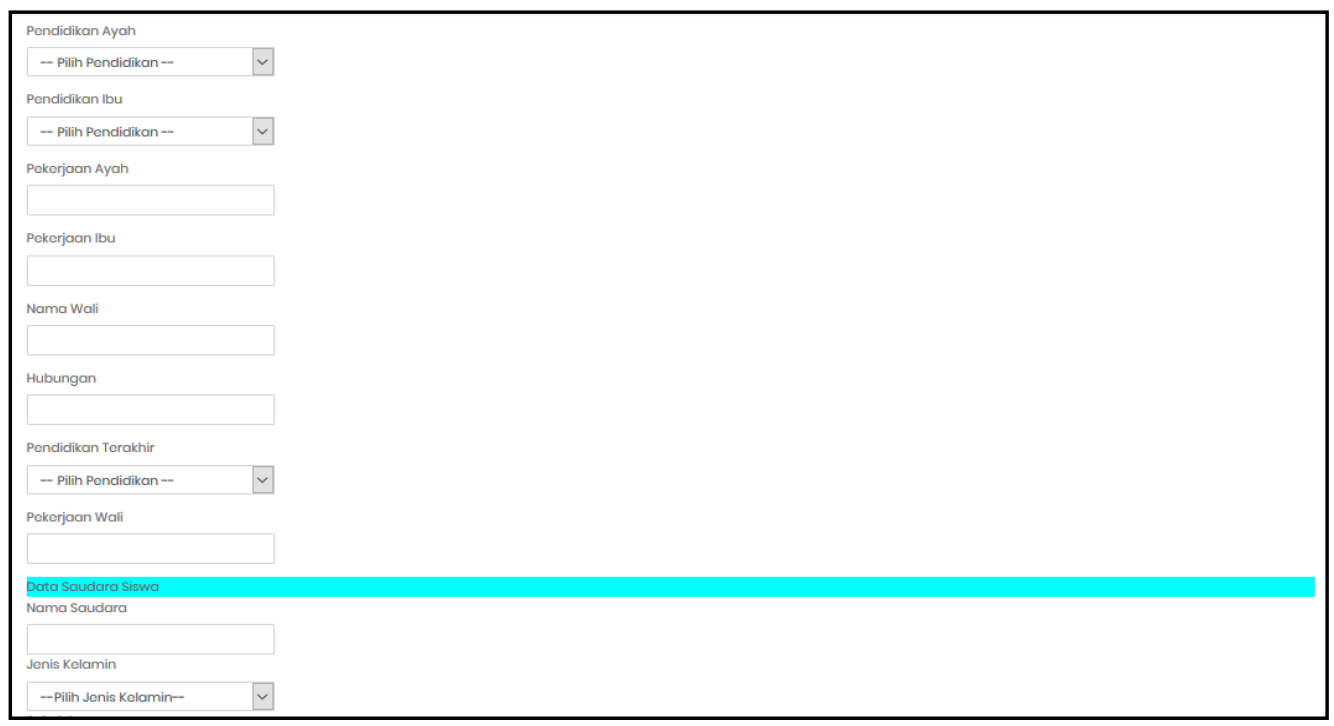

Gambar 7. Layar Pengelolaan Data Lanjutan (gambar 6)

Gambar diatas (gambar 7) merupakan rancangan layar untuk pengolahan data siswa, terdapat beberapa informasi yang diminta untuk dapat disimpan ke dalam database. 


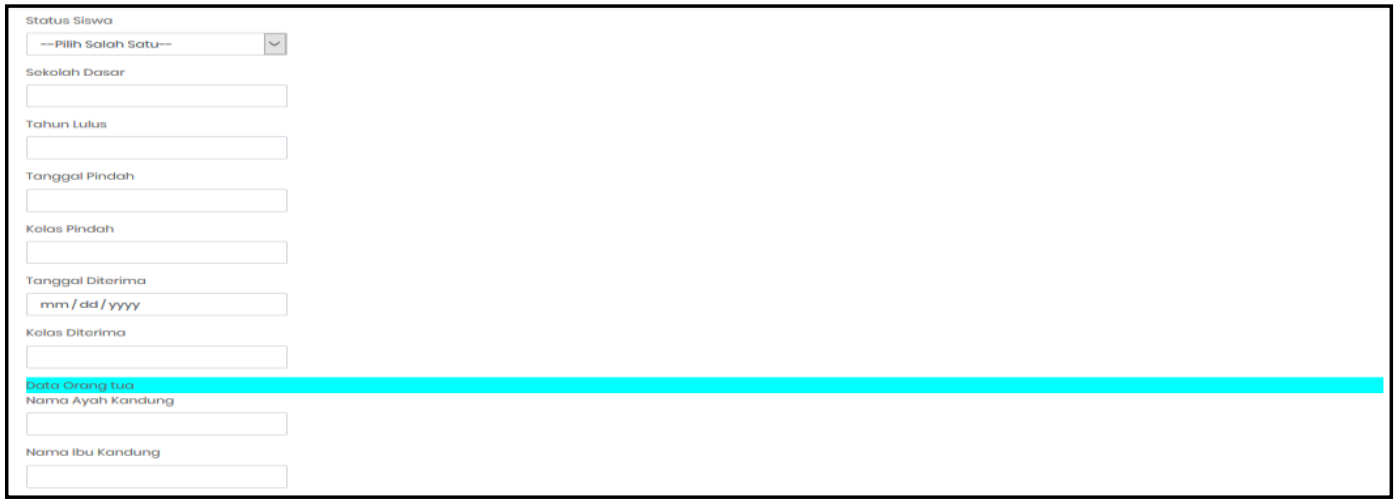

Gambar 8. Layar Pengelolaan Data Lanjutan (gambar 7)

Gambar diatas (gambar 8) merupakan lanjutan rancangan layar (gambar 7) untuk pengolahan data siswa, terdapat beberapa informasi yang diminta untuk dapat disimpan ke dalam database.

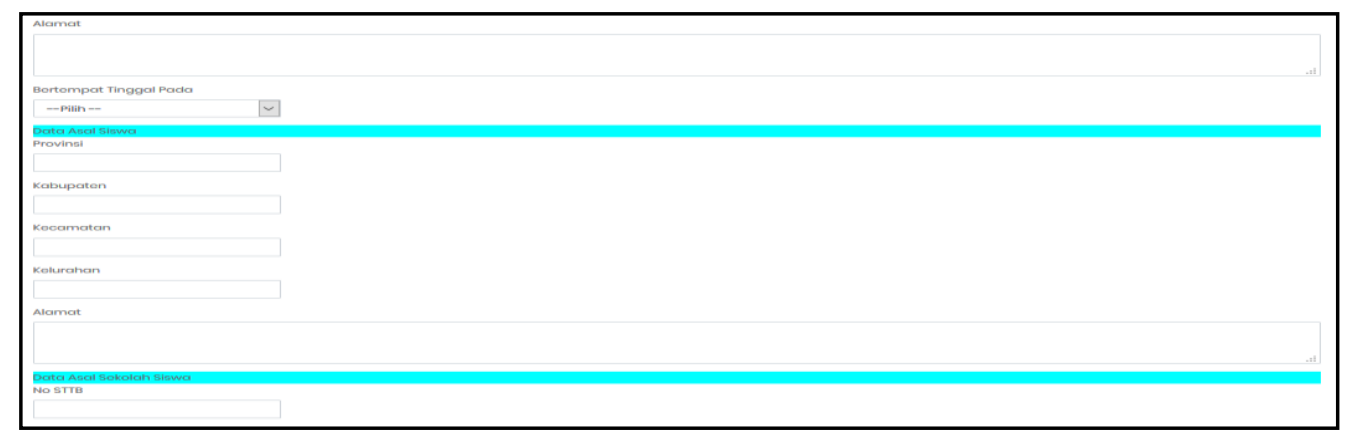

Gambar 9. Layar Pengelolaan Data Lanjutan (gambar 7)

Gambar diatas (gambar 9) merupakan lanjutan rancangan layar (gambar 7) untuk pengolahan data siswa, terdapat beberapa informasi yang diminta untuk dapat disimpan ke dalam database.

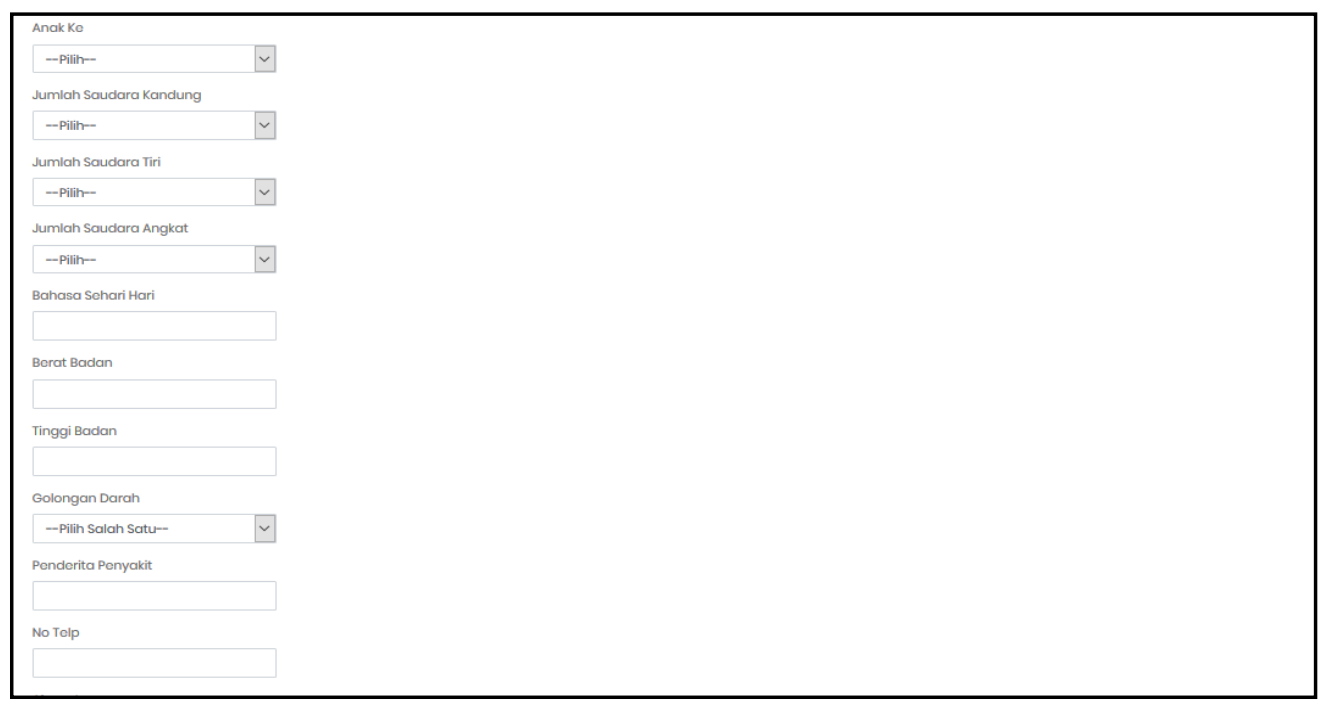

Gambar 10. Layar Pengelolaan Data Lanjutan (gambar 9) 
Gambar diatas (gambar 10) merupakan lanjutan rancangan layar (gambar 9) untuk pengolahan data siswa, terdapat beberapa informasi yang diminta untuk dapat disimpan ke dalam database

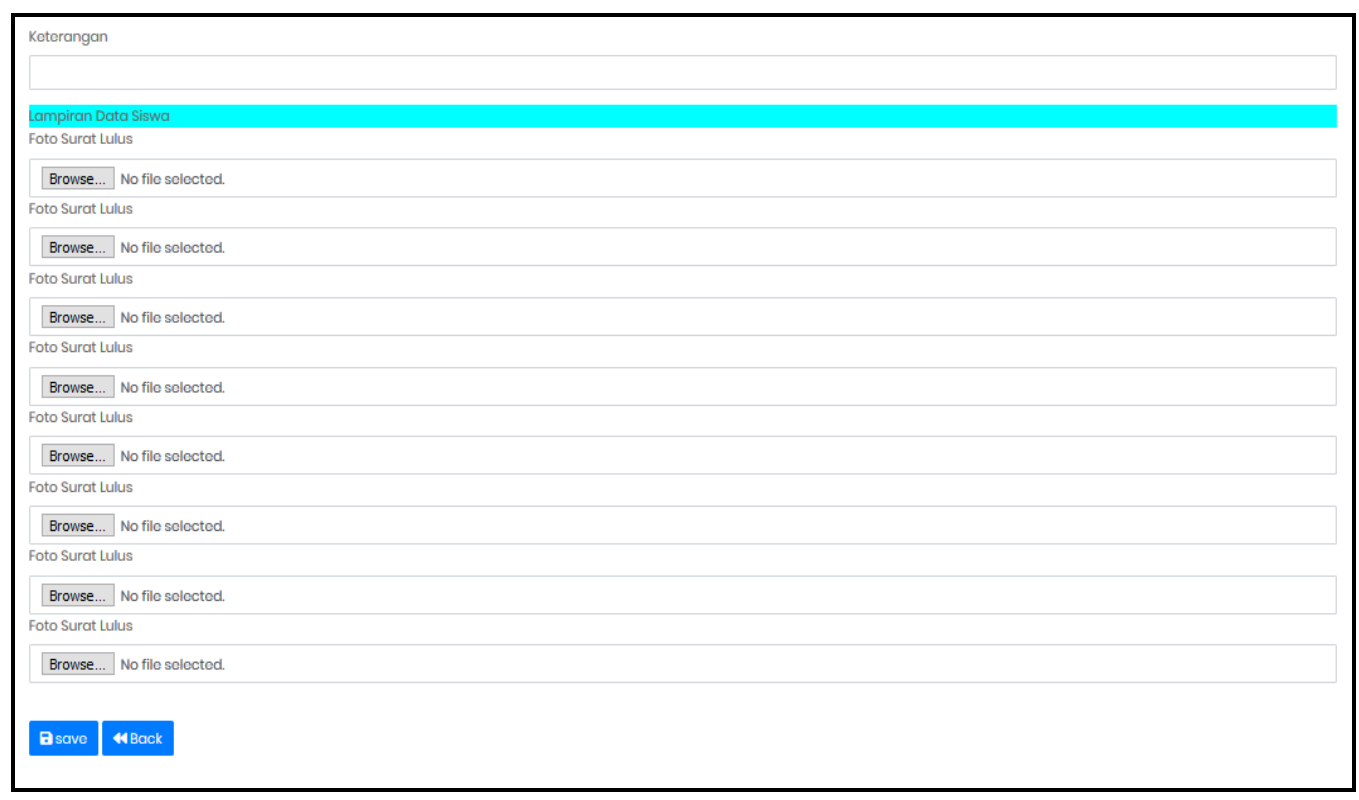

Gambar 11. Layar Pengelolaan Data Lanjutan (gambar 10)

Gambar diatas (gambar 11) merupakan lanjutan rancangan layar (gambar 10) untuk pengolahan data siswa, terdapat beberapa informasi yang diminta untuk dapat disimpan ke dalam database.

\section{Tampilan Layar Pendaftaran}

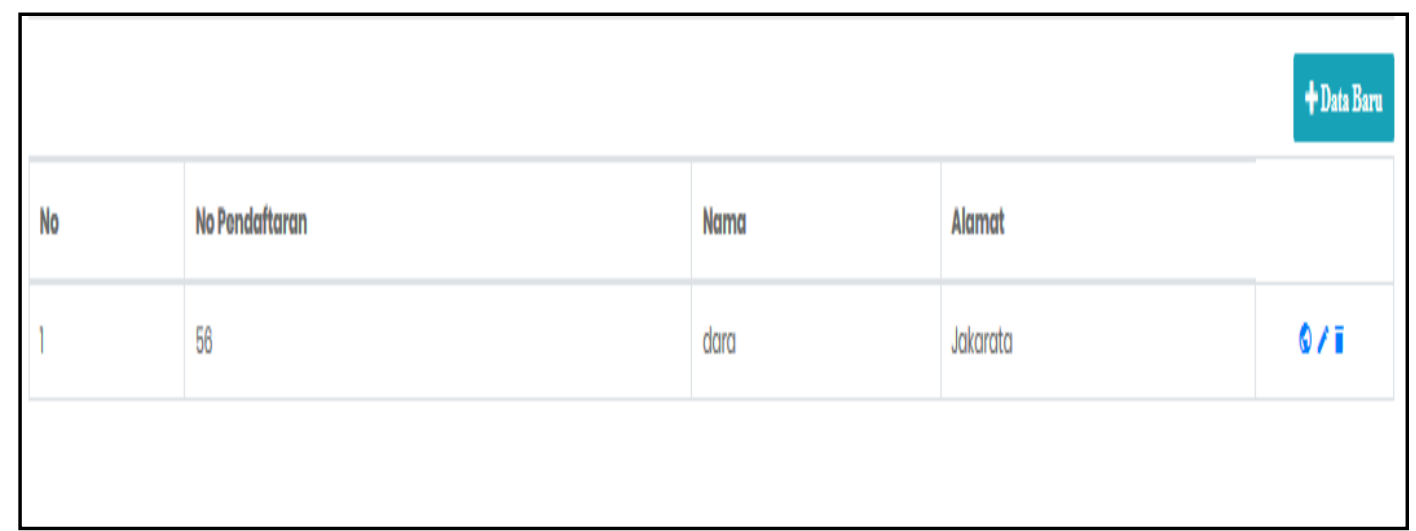

Gambar 12. Layar Pendaftaran Siswa Baru

Gambar diatas (gambar 12) menjelaskan tentang penginputan data barupendaftaran. Bagian ini dimaksudkan untuk mengetahui siapa saja yang sudah mengisi form pendaftaran, dan berasal dari wilayah mana saja. Kemudian data ini dapat di olah untuk menarik beberapa kesimpulan pemetaan berdasarkan wilayah, atau berdasarkan kategori lainnya yang dibutuhkan. 


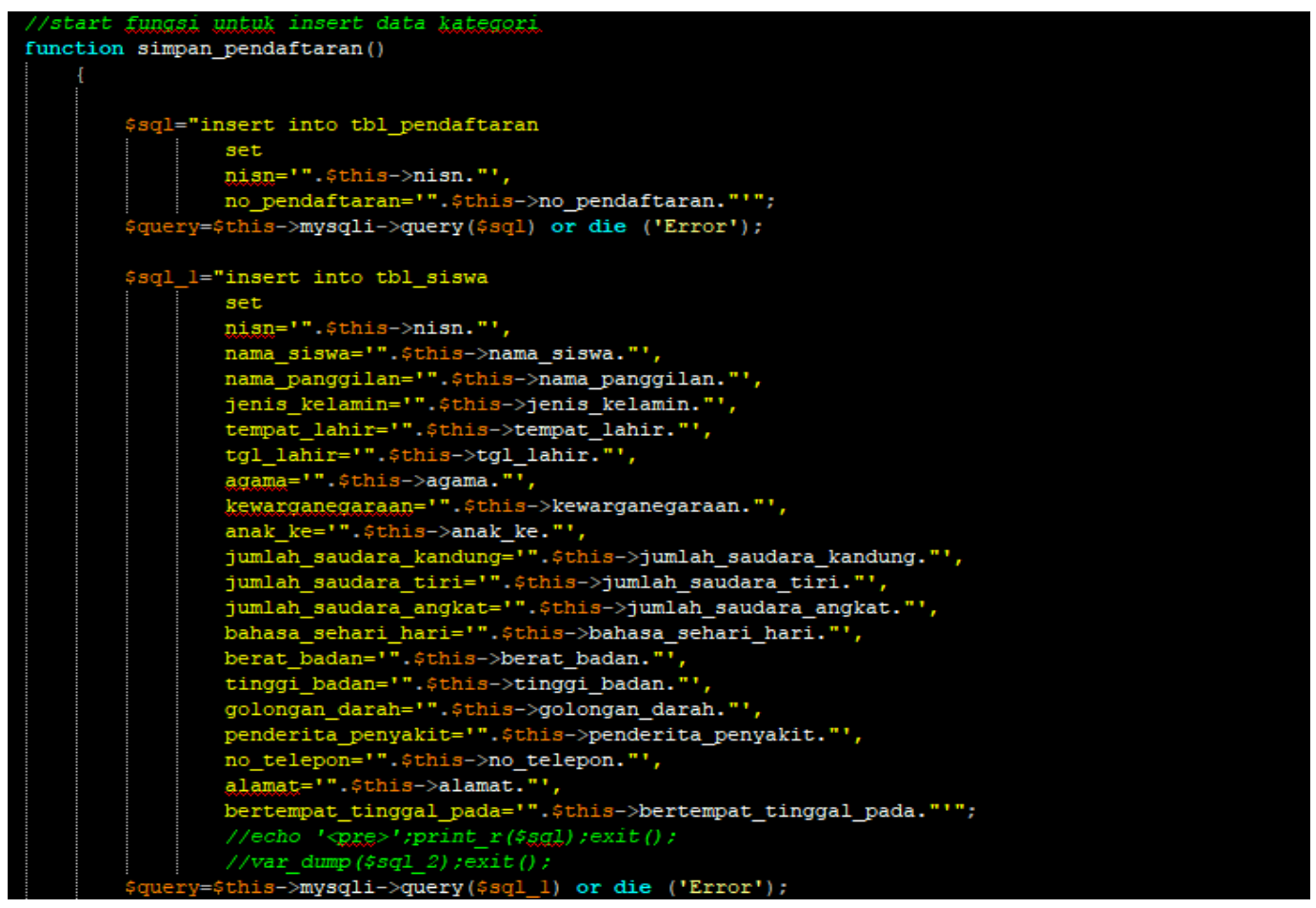

Gambar 13. Implementasi Script Coding Web Programming

Gambar diatas (gambar 13) merupakan bentuk implentasi pemrograman untuk web sesuai kebutuhan. Bahawa pemrograman yang digunakan adalah web programming dengan menggunakan bootstrap framework dan YII framework. Hasil implementasi web ini diharapkan dapat diakses secara online guna meningkatkan kemudahan, kecepatan dan kenyamanan buat calon pendaftar, bisa diakses dimanapun dan dari manapun.

\section{KESIMPULAN}

Hampir disebagian besar proses penyelenggarakan pendaftaran siswa baru disekolah masih dilakukan secara manual, hal ini terkadang menyebabkan tidak terjaringgnya calon siswa baru dari berbagai wilayah dan berbagai kalangan. Proses manualisasi yang terjadi, terkadang tak jarang memberikan informasi yang kurang valid dan kurang cepat, hal ini dimungkinkan karena untuk dapat melakukan pencarian data memerlukan waktu tambahan untuk dapat menyajikannya kembali, apalagi kalau bicara perihal laporan, sangat dirasakan kurang efektif dan efisien.

Model sistem yang diusulkan diharapkan dapat membantu para penyelenggara pendidikan sekolah terbantu dengan adanya sistem ini, karena selain proses yang cepat dan bisa diakses dari mana saja dan kapan saja, model yang di usulkan ini mampu menciptakan laporan dengan beberapa pilihan kategori, seperti laporan pendaftaran siswa berdasarkan pemetaan wilyah, berdasarkan hobi, berdasarkan tingkat ekonomi orang tua, dan masih banyak lagi yang lainnya. 


\section{DAFTAR PUSTAKA}

[1] Junaidi, Junaidi, Retno Setianingsih, and Khusnul Khotimah. "Rancang Bangun Sistem Penerimaan Dan Pengeluaran Barang Menggunakan Java Aplikasi." Proceedings Konferensi Nasional Sistem dan Informatika (KNS\&I) (2015).

[2] Junaidi, Junaidi, Abdul Roji, and Kharis Munawar. "Konsep Otomatisasi Sistem Pembayaran SPP Online Untuk Mengurangi Tingkat Keterlambatan." Proceedings Konferensi Nasional Sistem dan Informatika (KNS\&I) (2015).

[3] Rijan, Yunirman, and Ira Koesoemawati. "Cara Mudah Membuat Surat Perjanjian/Kontrak dan Surat Penting Lainnya." Raih Asa Sukses, Depok (2009).

[4] Junaidi, Junaidi, Ladyca Anugrah, and Adhitya Dwi Pancasakti. "Model Aplikasi Monitoring Sistem Absensi Sidik Jari Sebagai Pendukung Keputusan Untuk Penilaian Kinerja Pegawai." Proceedings Konferensi Nasional Sistem dan Informatika (KNS\&I) (2015).

[5] Sugianto. 2013. "Perancangan Sistem Informasi Penjualan Pada Butik Luwes Fashion Kecamatan Tulakan." Indonesian Jurnal on Computer Science-Speed (IJCSS) Vol 2 No 1 ISSN:2302-1136 (2013).

[6] Junaidi, Junaidi, Abdul Roji, and Kharis Munawar. "Konsep Otomatisasi Sistem Pembayaran SPP Online Untuk Mengurangi Tingkat Keterlambatan." Proceedings Konferensi Nasional Sistem dan Informatika (KNS\&I) (2015).

[7] Henderi, Henderi, Junaidi Junaidi, and Tubagus Ahmad Harja Kusuma. "Dashboard Monitoring System Penjualan Dan Reward Mobile Kios PT. Telekomunikasi Seluler." Semantik 2.1 (2012).

[8] Junaidi, Junaidi, Ridwan Arifin, and Amanda Septiani. "Rancang Bangun Aplikasi Sistem Inventory Berbasis Desktop Menggunakan JSE." Proceedings Konferensi Nasional Sistem dan Informatika (KNS\&I) (2015).

[9] Junaidi, Junaidi, Novi Cholisoh, and Nur Hasanah. "Rancang Bangun Sistem Manajemen Aset IT Untuk Pencatatan History Maintenance Sebagai Pendukung Keputusan." SENSI Journal 4.2 (2018): 220-231.

[10] Junaidi, Junaidi, Sugeng Santoso, and Lusyani Sunarya. "Rekayasa Teknik Pemrograman Pencegahan Dan Perlindungan Dari Virus Lokal Menggunakan API Visual Basic." CCIT Journal 1.2 (2008): 134-153. 